\title{
Jurnal
}

\section{STUDY ON PERFORMANCE OF HYBRID CELL OF DSSC AND PIEZOELECTRIC IN ONE ACTIVE AREA OF AZO NANOFIBER SEMICONDUCTOR}

\author{
Syamsul Hadia*, Mirza Yusufa, Budi Kristiawana, Atmanto Heru \\ Wibowo ${ }^{b}$, Suyitnoa
}

aMechanical Engineering Department, Sebelas Maret University, Jl. Ir Sutami 36A, Surakarta, Indonesia

bFaculty of Mathematics and Natural Sciences, Sebelas Maret University, JI. Ir Sutami 36A, Surakarta, Indonesia
Article history

Received

22 December 2016

Received in revised form

7 November 2017

Accepted

15 January 2018

Published online

1 April 2018

*Corresponding author

syamsulhadi@ft.uns.ac.id

\section{Graphical abstract}

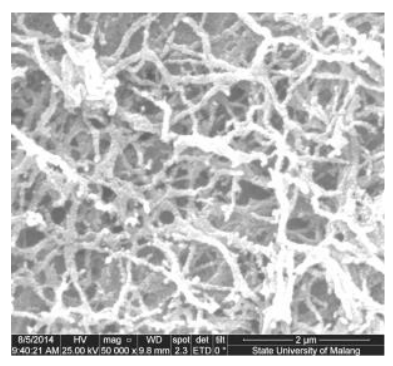

\begin{abstract}
This study aims to explore the possibilities of hybrid cells to convert photon and mechanical energies in a semiconductor area. A device with a hybrid ability was successfully fabricated from AZO (Al doped $\mathrm{ZnO}$ ) semiconductor nanofibre-based materials by an electrospinning method. The N-719 dye was used to synthesize the semiconductors. The hybrid cell of DSSC and piezoelectric use flowrates of precursor as a measurement parameter on the electrospinning machine which differences of nanofiber diameters were formed on the collector. Furthermore, aluminum as doping material was also applied to $\mathrm{ZnO}$ in order to reduce the size of the fibers. When the hybrid cell worked as solar cells based on AZO, an open circuit voltage was produced in the range of 0.421 to $0.507 \mathrm{~V}$. In greater flow of precursors condition, $V_{\text {oc }}$ of DSSC will be slightly decreased. On the AZObased DSSC, the highest Jsc was $1,147 \mathrm{~mA} / \mathrm{cm}^{2}$. When the cell worked as a power nano generator, $V_{o c}$ and highest output power of AZO-based cells were $119 \mathrm{mV}$ and 24,8 nW repectively on the flow rate of $2 \mu \mathrm{L} / \mathrm{min}$.
\end{abstract}

Keywords: Hibrid cell, DSSC, piezoelectric, Power Nano Generator, electrospinning, dye N719, flowrate, nanofiber, AZO, ZnO

(c) 2018 Penerbit UTM Press. All rights reserved

\subsection{INTRODUCTION}

Zinc Oxide (ZnO) known as unique semiconductor materials which was applied for several apparatus such as solar cells [1-3], gas sensor [4], and piezoelectric [5-9]. As a semiconductor material for solar cell, ZnO has functions to convert foton energy through electron excitation mechanism based on band gap. Compared to the $\mathrm{TiO}_{2}$ which has band gap of $4.24 \mathrm{eV}, \mathrm{ZnO}$ has bigger band gap value of $3.61 \mathrm{eV}$ [10] in which it effects the level of energy conversion of $\mathrm{ZnO}$ based solar cell that is lower than TiO2 based solar cell because of the smaller absorbance of the light for $\mathrm{ZnO}$. There are several factors having effect to the efficiency such as solvability of $\mathrm{ZnO}$ in dye immersion, the dye- aggregate formation of $\mathrm{Zn}^{2+}$, electron injection efficiency, efficiency of dye regeneration, and the density of the surface trap after dye absorpsion [11]. Generally in order to obtain optimal performance of the solar cells, several factors are required such as rapid electron injection, high dye uptake, long lifespan electrons and short time electron transfer [11]. Besides functioning as a solar cell material, Zno has already been studied as a piezoelectric material. Piezoelectric is an energy harvesting method which operates on the mechanical stress in order to generate electric power. This piezo effect could happen at materials which have noncentrosimetric crystal as shown on tetrahedral crystal of $\mathrm{ZnO}$ while crystale shape for TiO2 doesn't have piezo effect. This fact makes $\mathrm{ZnO}$ as an unique semiconductor 
material having capability on electron transfer on solar cell and mechanical stress effect. Unfortunately researches on hybrid of $\mathrm{ZnO}$ as energy harvester are still limited. Even though $\mathrm{ZnO}$ based solar cell has low efficiency compared to $\mathrm{S}_{\mathrm{O}} \mathrm{O} 2$ but the noncentrosimetric form of the crystal of $\mathrm{ZnO}$ has a capability to act as piezoelectric mechanism in one layer with solar cell [12].

In the previous hybrid cell study, ZnO was manufactured using screen printing method, while in the other fact $\mathrm{ZnO}$ could be fabricated in the fibre form by electrospinning method [13-14]. Compared to the round shape, $\mathrm{ZnO}$ fibre form has better color absorption and easier electron transfer because of mechanical stress. Compared to other synthesis methods of semiconductor such as spray pyrolysis deposition (SPD) [15], magnetron sputtering [12] solvothermal processing, and spin coating [16], electrospinning method is much easier especially in terms of parameters control and generates a form of nanofiber of semiconductor $[14,17,18,19,21]$.

So far electrospinning method to produce semiconductors for energy harvesters are still limited to a single source of energy and whereas the sources of the hybrid energy are still rare. This research focuses on the manufacturing process of hybrid cell of DSSC and piezoelectric in one cell of Al based ZnO (AZO) nanofiber and its performance as the effect of the precursor debit determining the fiber diameter on Al doped $\mathrm{ZnO}$ (AZO) in order to enhance the performance of $\mathrm{ZnO}$.

\subsection{METHODOLOGY}

Sinthesis process of the Al doped $\mathrm{ZnO}$ materials has already designed and manufactured. Nanofiber was formed by electrospinning machine using $1 \mathrm{ml}$ of solution in syringe pump at high voltage of $15 \mathrm{kV}$ attached to the horizontal collector plate on $8 \mathrm{~cm}$. The solution was push flow to the syringe on flow rate of $2,4,6$, and $8 \mu \mathrm{l} /$ minutes respectively which the green fibers will be collected. Green fibers then sintered at $550^{\circ} \mathrm{C}$ in 2 hours of holding time to eliminate organic material and formed ZnO crystal [13]. Most of the organic matter PVA and acetic acid were decomposed or lost at a temperature of $550^{\circ} \mathrm{C}$ [20] at the heating rate $240^{\circ} \mathrm{C} / \mathrm{hr}$. While other studies mention that the temperature of $420^{\circ} \mathrm{C}$ is enough to decompose the PVA organic material [21] due to the heating rate $600^{\circ} \mathrm{C} / \mathrm{hr}$. At those temperatures the semiconductor oxide will form a nanofiber of AZO. Characterization of nanofiber morphology and crystallinity of AZO were obtained by SEM and XRD test. Further XRF test was conducted to determine the content of doping that is not detected because of the very small quantities. The goal is to determine the presence of aluminum as a dopant material $\mathrm{ZnO}$ nanofiber.

\subsection{RESULTS AND DISCUSSION}

\subsection{Morphological Test of ZnO and AZO Fiber}

The SEM test showing fiber of AZO as a result of electrospinning machine in various debit of precursor in continuously shaped was presented on Figure 1. On the AZO fiber there is not fibrous condition. Further doping process of $\mathrm{Al}$ to $\mathrm{ZnO}$ decreases the size of fiber in $1 / 1.7$ to $1 / 2.3$. This condition is a result of nucleation center forming on $\mathrm{ZnO}$ in $\mathrm{Al}$ doping process [22], so in the similar sintering energy the size of the fiber will decrease. Furthermore the diameter size of AZO fiber is more uniform than $\mathrm{ZnO}$ as shown in smaller deviation standard (Table 1). For AZO, the smallest diameter of the fiber was obtained at a flow rate of precursor of $2 \mu \mathrm{L} / \mathrm{min}(85.0 \mathrm{~nm})$.

Table 1 The Mean diameter of AZO fiber at various flow rate of precursor

\begin{tabular}{ccccc}
\hline Flowrate & AZO-2 & AZO-4 & AZO-6 & AZO-8 \\
\hline Mean Diameter (nm) & 85.0 & 102.3 & 129.2 & 189.9 \\
Stdev & 18.7 & 16.3 & 18.6 & 59.4 \\
t-test (20 fiber) & 1.03 & 1.40 & 0.06 & 1.05 \\
\hline
\end{tabular}

In this research, the fiber diameter is slightly larger than those obtained in the previous studies which ranged from 65.3-82.8 $\mathrm{nm}$ at similar flow rate [23] because in the previous study the collector was aluminum plate that has a greater electrical conductivity than the glass FTO (fluorine-doped tin oxide). On the collector having higher electrical conductivity, the withdrawal speed of the fiber is higher producing fiber in smaller diameter.

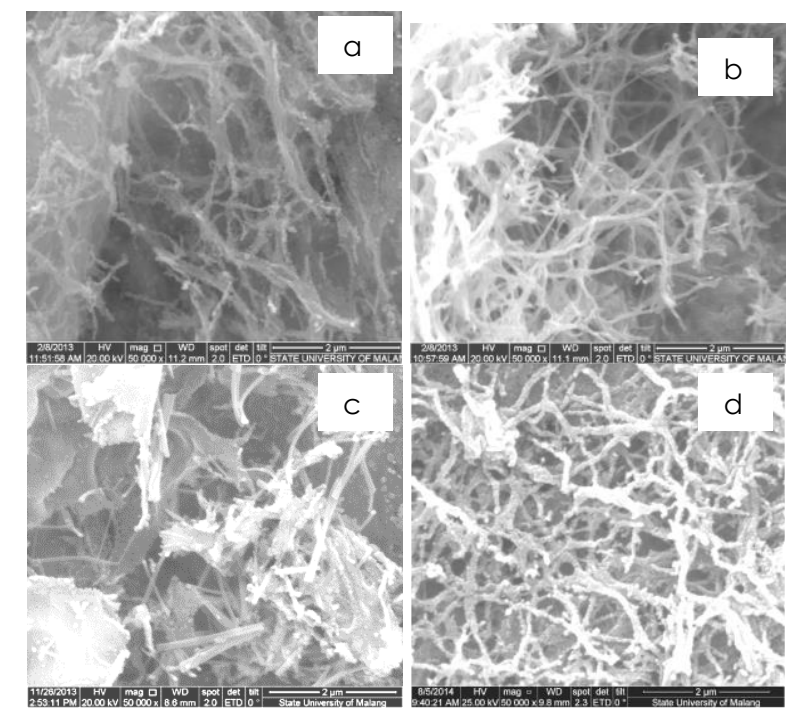

Figure 1 SEM photos of AZO nanofiber in various debit of precursor (a) $2 \mu \mathrm{L} / \mathrm{min}$, (b) $4 \mu \mathrm{L} / \mathrm{min}$, (c) $6 \mu \mathrm{L} / \mathrm{min}$, (d) 8 $\mu \mathrm{L} / \mathrm{min}$ 
Meanwhile, based on JC-PDF 36-1451 of the XRD test for AZO fiber shows three main diffraction peaks at index of (100), (002) and (101) corresponding to the hexagonal structure of $\mathrm{ZnO}$. The doping process of aluminum in the $\mathrm{ZnO}$ does not change the pattern of X-ray diffraction and nor emerge a new phase. It means that aluminum succeeds in infiltrating the crystal lattice of $\mathrm{ZnO}$ depicted by bigger size of the crystals of $\mathrm{AZO}$, as shown in Figure 2.

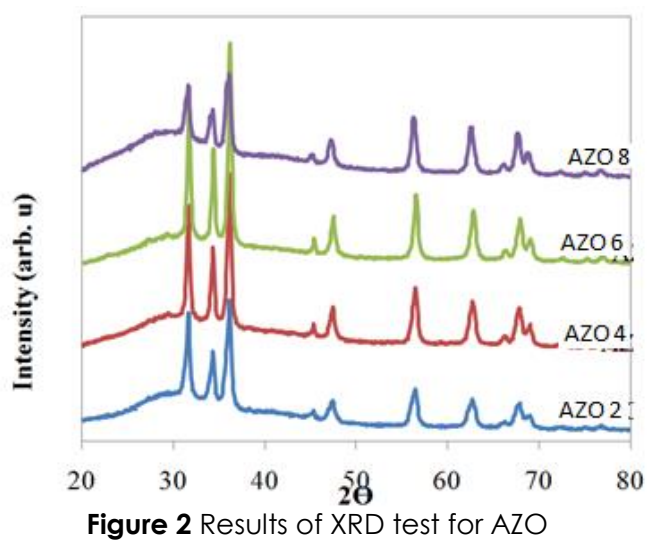

The presence of $\mathrm{Al}$ does not change the energy band gap and crystallinity of fiber both of $\mathrm{ZnO}$ and $\mathrm{AZO}$. The band gap value of AZO ranged from 3.18 to 3.20 , while the crystallinity value from 75.53 to $80.18 \%$ as shown in Table 2. Meanwhile, the rate of precursor led to an increase in the value of the band gap. The size or spacing of the crystal AZO was calculated by the Debye-Scherrer formula at the highest peak [13]. Meanwhile, Williamson and Hall explained that the strain $(\epsilon)$ on the crystal can cause changes in the size of the crystal. According to Williamson-Hall equations, crystal size and strain relationships can be expressed [14]. On AZO, the fiber crystal size is also influenced by the rate of precursor during the process electrospinning. The biggest crystal size in the fiber AZO precursor occurs at the rate of $6 \mu \mathrm{L} / \mathrm{min}$. Due to the existing strain, the crystal size is also increasing.

Table 2 Band gap, size of crystal, dan cristallinity of $\mathrm{ZnO}$ and AZO fiber

\begin{tabular}{cccccc}
\hline $\begin{array}{c}\text { Rate of } \\
\text { Precurso } \\
\mathbf{r}\end{array}$ & $\begin{array}{c}\text { Band } \\
\text { gap } \\
(\mathbf{e V})\end{array}$ & $\begin{array}{c}\text { Cryst } \\
\text { allinit } \\
\mathbf{y}(\%)\end{array}$ & $\begin{array}{c}\text { Crystalli- } \\
\text { ne size- } \\
\text { Debye- } \\
\text { Scherrer } \\
(\mathbf{n m})\end{array}$ & $\begin{array}{c}\text { Crystalline } \\
\text { size- } \\
\text { Williamson } \\
\text {-Hall } \\
(\mathbf{n m})\end{array}$ & $\begin{array}{c}\text { Strain } \\
(\%)\end{array}$ \\
\hline 2 AZO & 3.18 & 74.53 & 14.5 & 30.1 & 0.314 \\
4 AZO & 3.19 & 74.90 & 18.2 & 42.0 & 0.287 \\
6 AZO & 3.18 & 73.65 & 20.3 & 47.6 & 0.265 \\
8 AZO & 3.20 & 80.18 & 13.9 & 15.9 & 0.003 \\
\hline
\end{tabular}

\subsection{The Performance of Hybrid Cell}

Basically, the hybrid cell is DSSC solar cells which part of the counter electrode is free to move with the elasticity obtained from rubber attached behind the electrode. When it was exposed to light the hybrid cells function as a solar cells and when the load was forced the hybrid cell serving as piezoelectric. The performance of the hybrid cells when is exposed to light can be seen in Figure 3. While, the performance of the hybrid cells when is subjected to a load can be seen in Figure 4 and Figure 5.

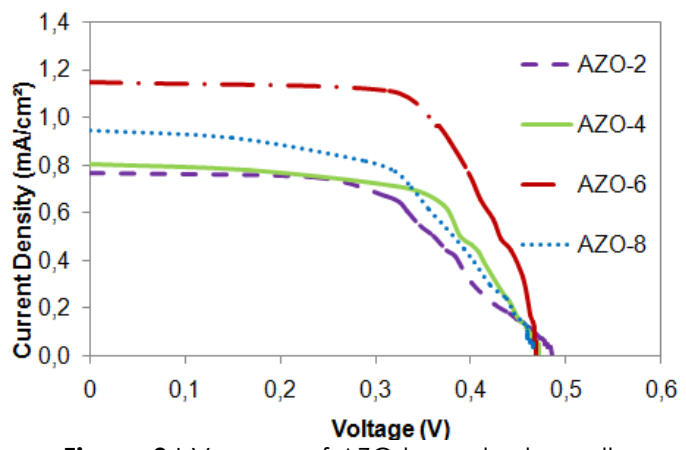

Figure $3 \mathrm{I}-\mathrm{V}$ curve of AZO based solar cells

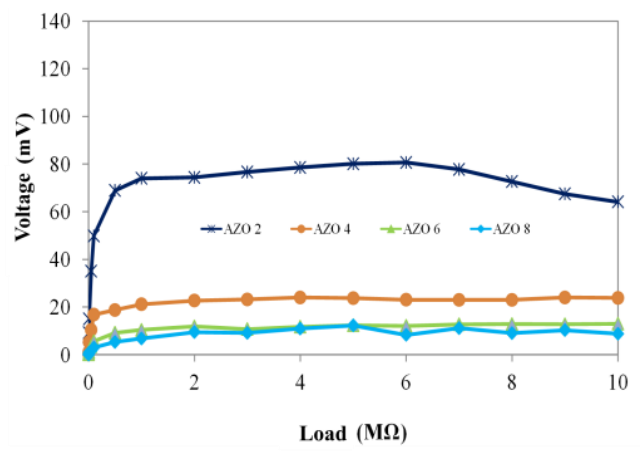

Figure 4 Measured Voltage of AZO based piezoelectrics

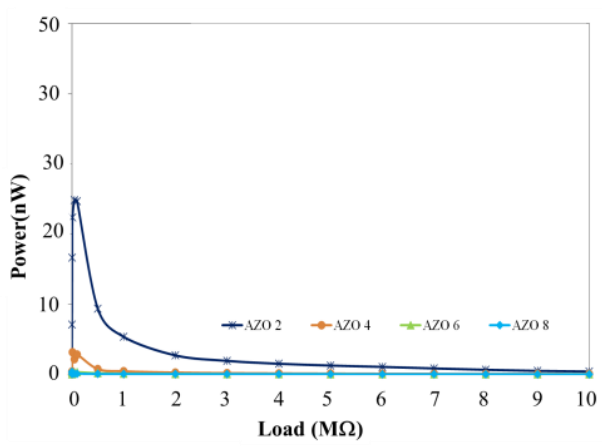

Figure 5 Output power of AZO based piezoelectrics

The performance of hybrid cell that works as a AZO-based solar cells was shown by the value of open circuit voltage, $V_{\text {oc }}$, between 0.465 to $0.486 \mathrm{~V}$ depending on the electrospinning pump discharge. The greater flow of precursors slightly lowers $V_{\text {oc }}$ as the effect of higher energy band gap on semiconductor, as shown in Table 3. Furthermore, the magnitude of $J_{s c}$ on ZnO-based solar cells is sharply decreased by increasing the flow rate of 
electrospining precursors as shown in Table 3. In the same area, when the particle size of $\mathrm{ZnO}$ becomes greater the amount of the bond between the semiconductor particles and a dye molecule becomes lower. The $J_{\text {sc }}$ value depends on the anchoring and bonding process between the semiconductor particles and the dye molecule [26].

Table 3 Performance of hybrid cell as DSSC

\begin{tabular}{|c|c|c|c|c|c|}
\hline \multirow[b]{2}{*}{ Precursor } & \multirow{2}{*}{$\begin{array}{l}\text { Flow rate } \\
(\mu \mathrm{L} / \mathrm{min})\end{array}$} & \multicolumn{4}{|c|}{ Solar Cell } \\
\hline & & $\begin{array}{l}V_{o c} \\
\text { (V) }\end{array}$ & $\begin{array}{c}J_{\mathrm{sc}} \\
\left(\mathrm{mA} / \mathrm{cm}^{2}\right)\end{array}$ & $\begin{array}{c}F F \\
(\%)\end{array}$ & $\begin{array}{c}\text { Efficiency } \\
(\%)\end{array}$ \\
\hline \multirow{4}{*}{ 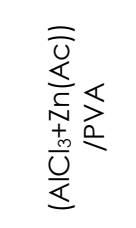 } & 2 & 0.486 & 0.767 & 56.2 & 0.21 \\
\hline & 4 & 0.471 & 0.806 & 62.0 & 0.24 \\
\hline & 6 & 0.468 & 1.147 & 65.5 & 0.35 \\
\hline & 8 & 0.465 & 0.947 & 56.2 & 0.25 \\
\hline
\end{tabular}

Besides, for the hybrid AZO based solar cells, Jsc value increases by increasing flow rate of precursor until $6 \mu \mathrm{L} / \mathrm{min}$ and then drops back. The highest $J_{\text {sc }}$ of AZO is $1.147 \mathrm{~mA} / \mathrm{cm}^{2}$. The value of $J_{s c}$ was determined by small size of fiber and uniformity of fiber AZO. Uniformity of fiber was marked by the low t-test values (Table 1) which facilitates the flow of electrons. The fiber uniformity has become a major issue in addition to the size of the fiber on fiber synthesis process by using electrospinning machine [27].

Furthermore, Table 3 also shows that the Fill Factor (FF) and the efficiency of AZO based solar cells. The small size or diameter of AZO fiber effects the increasing $J_{s c}$ and the efficiency in the next. The highest efficiency of hybrid AZO based solar cells of $0.35 \%$ was obtained at precursor flow rate of 6 $\mu \mathrm{L} / \mathrm{min}$. The highest efficiency in DSSC with AZO-6 correlates with the grain size of $\mathrm{S}_{n} \mathrm{O}_{2}: \mathrm{F}$ on $\mathrm{FTO}$ of 470 $\mathrm{nm}$ [28]. Better contact occurs on size of fibers from 129.2 to $142.7 \mathrm{~nm}$ semiconductor. After the performance of hybrid cells in converting light energy into electricity was measured, the performance in converting mechani-cal energy into electricity was also counted. The cells which have a capability to convert mechanical energy into electricity is called piezoelectric nanogenerator (PNG) and its performance is shown in Table 4.

Table 4 Performance of hybrid cell as piezoelectric

\begin{tabular}{|c|c|c|c|}
\hline \multirow{2}{*}{ Precursor } & \multirow{2}{*}{$\begin{array}{c}\text { Flow } \\
\text { rate } \\
(\mu \mathrm{L} / \mathrm{min})\end{array}$} & \multicolumn{2}{|c|}{ Piezoelectric Nano Generator } \\
\hline & & $\mathrm{V}_{\mathrm{oc}}(\mathrm{mV})$ & Max Power (nW) \\
\hline \multirow{4}{*}{ 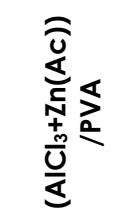 } & 2 & 119 & 24.8 \\
\hline & 4 & 27 & 3.2 \\
\hline & 6 & 13 & 0.4 \\
\hline & 8 & 14 & 0.4 \\
\hline
\end{tabular}

For the AZO based PNG, the highest $V_{\text {oc }}$ of $119 \mathrm{mV}$ with generated power of $24.8 \mathrm{NW}$ was obtained at the flow rate of $2 \mu \mathrm{L} / \mathrm{min}$. This $V_{\text {oc }}$ value is higher than the value of $V_{o c}$ in a thin layer of ZnO-PSS/PVA of 10$100 \mathrm{mV}$ [29]. The highest output power value on the ZnO based PNG is also higher than the PZT fibers based PNG with an output power of $30 \mathrm{nW}$ at $6 \mathrm{M} \Omega$ [30]. Voltage and power output of PNG were strongly influenced by the position of $\mathrm{Zn}$ and $\mathrm{O}$ atoms in $\mathrm{a}$ hexagonal structure of $\mathrm{ZnO}$, because the changes in the dipole are formed by the difference in electronegativity and the position of these two atoms. On the AZO based PNG, the size of crystal structure was expanded because of strain existence compared to the size of the crystal without the strain, as shown in Table 4. The existence of a large strain makes two atoms in apart position so the generated voltage is increased. The presence of aluminum doping in $\mathrm{ZnO}$ effects the fiber size to shrink and also leads to produce low strain so both of voltage and power output on AZO based PNG are low.

\subsection{CONCLUSION}

This paper has presented a doping process of aluminum in the $\mathrm{ZnO}$ as a material of hybrid cell of solar cell (DSSC) and piezoelectric modul which causes decreasing the synthesed fiber size and lowering strain that affect to the voltage and output power. A module of hybrid cell of solar cell (DSSC) and piezoelectric with fiber (nanofiber) semiconductor of $\mathrm{AZO}$ was also successfully fabricated using electrospinning engine. The performance of hybrid cell of DSSC for open circuit voltage was in the range of 0.421 to $0.507 \mathrm{~V}$. The highest JSC value of AZO based DSSC nanofiber was $1.147 \mathrm{~mA} / \mathrm{cm} 2$. Finally at precursor rate of $2 \mu \mathrm{L} / \mathrm{min}$ the highest $\mathrm{VOC}$ of AZO based PNG of $119 \mathrm{mV}$ and power output of $24.8 \mathrm{nW}$ was obtained.

\section{Acknowledgement}

This work is supported by LPPM Sebelas Maret University under Indonesian Ministry of National Education and Culture and performed by research group of Applied Energy Conversion and Nanotechnology under Mechanical Engineering Department of Sebelas Maret University.

\section{References}

[1] Kim, Kang, Y.-S., Lee, J.-H., Shin, Y.-J., Park, N.-G., Ryu, K.S., et al. 2006. Photovoltaic Properties of Nano-Particulate and Nanorod Array Zno Electrodes for Dye-Sensitized Solar Cell. Bull. Korean Chem. Soc. 27(2): 295-298.

[2] Suri, Panwar, M., and Mehra, R. M. 2007. Photovoltaic Performance of Dye-Sensitized Zno Solar Cell Based on Eosin-Y Photosensitizer. Materials Science-Poland. 25(1): 137-144. 
[3] Yang, XU, T., Ito, Y., Welp, U., and Kwok, W. K. 2009 Enhanced Electron Transport in Dye-sensitized Solar Cells Using Short Zno Nanotips on a Rough Metal Anode. J. Phys. Chem. C. 113: 20521-20526.

[4] Kashyout, Soliman, H. M., Hassan, H. S., and Abousehly, A. M. 2010, Frabrication of Zno and Zno:Sb Nanoparticles for Gas Sensor Applications. Journal of Nanomaterials. 1-8.

[5] Lee, Lee, S.S., Choi, J.-J., Jeon, J. U., and Ro, K. 2005. Fabrication of a Zno Piezoelectric Micro Cantilever with a High-Aspect-Ratio Nano Tip. Microsystem Technologies. 11: 416-423.

[6] Chang, J., Dommer, M., Chang, C., and Lin, L. 2012 Piezoelectric Nanofibers for Energy Scavenging Applications. Nano Energy. 1: 356-371

[7] Pan, Wu, T.-H., Bui, T.-A., and Shih, W.-C. 2012. Fabrication of Highly C-Axis Textured Zno Thin Films Piezoelectric Transducers by Rf Sputtering. J Mater Sci: Mater Electron. 23: 418-424.

[8] Herng, A. Kumar, C. S. Ong, Y. P. Feng, Y. H. Lu, Zeng, K. Y., et al. 2012. Investigation of the Non-Volatile Resistance Change in Noncentrosymmetric Compounds. Scientific Reports Vol. 587.

[9] Grätzel, M. 2003. Dye-sensitized Solar Cells. Photochemistry and Photobiology C. 4: 145-153.

[10] Grätzel. 2001. Photoelectrochemical Cells. Nature Mater. 414: 338-344.

[11] Wong, Chan, W. K., Yu, L., and Phillips, D. L. 2012. Effect of Zno Nanoparticle Properties on Dye-sensitized Solar Cell. ACS Appl. Mater. Interfaces. 4: 1254-1261.

[12] Choi, Lee, K. Y., Lee, K. H., Kim, E. S., Kim, T. S., Lee, S. Y., et al. 2010. Piezoelectric Touch-Sensitive Flexible Hybrid Energy Harvesting Nanoarchitectures. Nanotechnology. 21 (40): 405-503.

[13] Park, Moon, J., Lee, S.-j., Lim, S.-c., and Zyung, T. 2009. Fabrication and Characterization of Zno Nanofibers by Electrospinning. Current Applied Physics. 9(3): \$210-\$212.

[14] Ren, Ding, Y., Jiang, Y., XU, F., Long, Z., and Zhang, P. 2009. Synthesis and Properties of Zno Nanofibers Prepared by Electrospinning. Journal of SolGel Science and Technology. 52(2): 287-290.

[15] Okuya, Koji Nakade, Daisuke Osa, Takafumi Nakano, G.R. Asoka Kumara, and Kaneko, S., 2004, Fabrication of DyeSensitized Solar Cells by Spray Pyrolysis deposition (SPD) technique. Journal of Photochemistry and Photobiology A: Chemistry. 164(1-3): 167-172.

[16] Takanezawa, Hirota, K., Wei, Q.-S., Tajima, K., and and Kazuhito Hashimoto. 2007. Efficient Charge Collection with Zno Nanorod Array in Hybrid Photovoltaic Devices. J. Phys. Chem. C. 111.

[17] Baek, Jeong-Ha Park, Ju-Yun Kang, Ji-Soo Kim, Don Koh, Sung-Wi Kang, et al. 2012. Fabrication and Thermal Oxidation of Zno Nanofibers Prepared Via Electrospinning
Technique. Bulletin of the Korean Chemical Society. 33(8): 2694-2698.

[18] Sangkhaprom, Naratip, Supaphol, P., and Pavarajarn, V. 2010. Fibrous Zinc Oxide Prepared by Combined Electrospinning and Solvothermal Techniques. Ceramics International. 36(1): 357-363.

[19] Park, and Kim, S. S. 2009. Growth of Nanograins in Electrospun Zno Nanofibers. The American Ceramics Society. 16691-11694.

[20] Yang, Shao, C., Guan, H., Li, X., and Gong, J. 2004 Preparation and Characterization of Zno Nanofibers by Using Electrospun Pva/Zinc Acetate Composite Fiber as Precursor. Inorganic Chemistry Communication. 7: 176178.

[21] Park, Moon, J., Lee, S.J., Lim, S. C., and Zyung, T. 2009. Fabrication and Characterization of Zno Nanofibers by Electrospinning. Current Applied Physics. 9: \$210-\$212.

[22] Deuk, J.-E. C., Nam-Ihn Chob, Myung-Hyun Leec, Se-Jong Leed, and Kime, B.-Y. 2008. Characterization of Electrospun Aluminum-Doped Zinc Oxide Nanofibers, Elsevier. 517.

[23] Suyitno, Purwanto, A., Hidayat, R. L. L. G., Sholahudin, I., Yusuf, M., Huda, S., et al. 2014, Fabrication and Characterization of Zinc Oxide-based Electrospun Nanofibers for Mechanical Energy Harvesting. Journal of Nanotechnology in Engineering and Medicine. 5(1).

[24] Kanjwal, Sheikh, F. A., and N. A. M, B. 2011. Co3o4-Zno Nanofiber Their Properties. Journal Nanoenginering and Nanomanufacturing. 1: 196-202.

[25] Mote, V. D., Purushotham, Y., and Dole, B. N. 2012. Williamson-Hall Analysis in Estimation of Lattice Strain in Nanometer-sized ZnO Particles. Journal of Theoretical and Applied Physics. 6: 6.

[26] Ooyama, Y., and Harima, Y. 2012. Photophysical and Electrochemical Properties, and Molecular Structures of Organic Dyes for Dye-sensitized Solar Cells. ChemPhysChem. 13(18): 4032-4080.

[27] Suyitno, Huda, S., Arifin, Z., Hadi, S., and Lambang, R. L. 2014. Repeatability and Reproducibility of Fibre-based Nanogenerator Synthesized by Electrospinning Machine. IOP Conference Series: Materials Science and Engineering. 58(1): 1-8.

[28] Suyitno, Arifin, Z., Santoso, A. A., Setyaji, A. T., and Ubaidillah. 2014. Optimization Parameters and Synthesis of Fluorine Doped Tin Oxide for Dye-sensitized Solar Cells. Applied Mechanics and Materials. 575: 689-695.

[29] Loh, K. J., and Chang, D. 2011. Zinc Oxide NanoparticlePolymeric Thin Films for Dynamic Strain Sensing. J Mater Sci. 46: 228-237.

[30] Chen, $X u$, S., Yao, N., and Shi, Y. 2010. $1.6 \mathrm{~V}$ Nanogenerator for Mechanical Energy Harvesting Using Pzt Nanofibers. Nano Letters. 10: 2133-2137. 